\title{
Building the capacity of users and producers of evidence in health policy and systems research for better control of endemic diseases in Nigeria: a situational analysis
}

Obinna Onwujekwe ${ }^{1,2}$, Enyi Etiaba ${ }^{1,2}$, Chinyere Mbachu ${ }^{1,3,4}$, Uchenna Ezenwaka ${ }^{1,2^{*}}$ (D) Ifeanyi Chikezie ${ }^{1}$ Ifeyinwa Arize ${ }^{1,2}$, Chikezie Nwankwor ${ }^{1,2}$ and Benjamin Uzochukwu $u^{1,3,4}$

\begin{abstract}
Background: There is a current need to build the capacity of Health Policy and Systems Research + Analysis (HPSR+A) in low and middle-income countries (LMICS) as this enhances the processes of decision-making at all levels of the health system. This paper provides information on the HPSR+A knowledge and practice among producers and users of evidence in priority setting for HPSR+A regarding control of endemic diseases in two states in Nigeria. It also highlights the HPSR+A capacity building needs and interventions that will lead to increased HPSR+A and use for actual policy and decision making by the government and other policy actors.

Methods: Data was collected from 96 purposively selected respondents who are either researchers/ academia (producers of evidence) and policy/decision-makers, programme/project managers (users of evidence) in Enugu and Anambra states, southeast Nigeria. A pre-tested questionnaire was the data collection tool. Analysis was by univariate and bivariate analyses.

Results: The knowledge on HPSR+A was moderate and many respondents understood the importance of evidence-based decision making. Majority of researcher stated their preferred channel of dissemination of research finding to be journal publication. The mean percentage of using HPSR evidence for programme design \& implementation of endemic disease among users of evidence was poor (18.8\%) in both states. There is a high level of awareness of the use of evidence to inform policy across the two states and some of the respondents have used some evidence in their work.
\end{abstract}

Conclusion: The high level of awareness of the use of HPSR+A evidence for decision making did not translate to the significant actual use of evidence for policy making. The major reasons bordered on lack of autonomy in decision making. Hence, the existing yawning gap in use of evidence has to be bridged for a strengthening of the health system with evidence.

Keywords: Capacity building, Endemic diseases, Health policy and systems research+ analysis, Producers of evidence, Users of evidence

\footnotetext{
* Correspondence: ezenwakauche@yahoo.com

'Health Policy Research Group, Department of Pharmacology and

Therapeutics, College of Medicine, University of Nigeria Enugu-Campus,

Enugu, Nigeria

${ }^{2}$ Department of Health Administration and Management, Faculty of Health

Science and Technology, College of Medicine, University of Nigeria

Enugu-Campus, Enugu, Nigeria

Full list of author information is available at the end of the article
}

(c) The Author(s). 2019 Open Access This article is distributed under the terms of the Creative Commons Attribution 4.0 International License (http://creativecommons.org/licenses/by/4.0/), which permits unrestricted use, distribution, and reproduction in any medium, provided you give appropriate credit to the original author(s) and the source, provide a link to the Creative Commons license, and indicate if changes were made. The Creative Commons Public Domain Dedication waiver (http://creativecommons.org/publicdomain/zero/1.0/) applies to the data made available in this article, unless otherwise stated. 


\section{Background}

Endemic tropical diseases continue to impose a tremendous health burden in resource-poor countries throughout the world, claiming millions of lives annually and inflicting severe morbidity that results in significant losses in economic productivity and social progress [1]. Nigeria did not meet the Millennium Development Goals (MDG) targets for malaria which was to halt and reverse the spread of malaria and some other communicable diseases such as HIV/AIDs, tuberculosis by 2015. The baseline assessment for the health-related Sustainable Development Goals (SDGs) highlights the weaknesses of the Nigerian health system in controlling of endemic diseases [2, 3]. A significant weakness is the scarcity of scientists and health professionals in low and middle-income countries (LMICs) with relevant infectious disease research knowledge and expertise to generate health policy and systems research evidence [4]. A second weakness is the limited use of relevant research evidence for policy and decision making, which essentially hinders well-designed disease control programs from achieving desired goals [5]. There is also the gap in evidence of complex interventions in health to improve knowledge of what works for whom and in what context $[6,7]$.

As policy-makers and communities increasingly demand better returns on investments in health, HPSR $+\mathrm{A}$ has the potential to enable health system interventions to achieve better value for money. However, the current capacity to undertake HPSR $+\mathrm{A}$ and teaching is low in developing countries [7]. Health policy and systems research has been defined as "an emerging field that seeks to understand and improve how the societies organize themselves in achieving collective health goals, and how different actors interact in the policy and implementation processes to contribute to health policy outcomes" [8]. It enables the identification of gaps in capacity, barriers to efficient functioning, and effective performance of the health system and methods by which the existing resources can be optimally utilized [9, 10]. Capacity building programs bring on additional resources, i.e. knowledge, skills and experiences in organizational settings [11]. HPSR is typically context-specific, and to apply research evidence to policy, national-level capacity is needed [7]. The success of efforts to build capacity in developing countries will ultimately depend on political will and credibility, adequate financing, and responsive research, capacity, strengthening (RCS) plan that builds on a thorough situational analysis of the resources needed for health research and the inequities and gaps in health care [12].

In order to strengthen health systems using evidence, there is a current need to build the capacity of
HPSR $+\mathrm{A}$ in LMICs as this encompasses the processes of actual decision-making at all levels of the health system [8]. Capacity building programs are critical for prioritizing health programs in resource-constrained countries where poor health outcomes have been linked with poor health services [11]. There is a rising importance to build capacity in $\mathrm{HPSR}+\mathrm{A}$ in both the 'pull and push' domains of research in Nigeria [13]. This includes capacity to analyse, evaluate, and develop context-specific strategies to strengthen the fight against neglected tropical diseases (NTDs) and malaria. It also encompasses capacity to demand for and use research, so that research knowledge contributes to improvements in health and health equity [13]. Several factors contribute to poor demand for research evidence. First is that there is little appreciation of the value of research and its potential to contribute to policy development. Another critical contributor is that many LMICs do not have an environment or a culture conducive to health research [13]. These environmental factors include governance, socio-political influences and attitude of key stakeholders.

In Nigeria, Universities are central to strengthening and sustaining HPSR+A capacity. They not only produce knowledge through research but are also mandated to teach the next generation of policy-makers, health professionals, and researchers [7]. However, there is limited capacity amongst these groups due to the long-standing culture of not making research a priority and poor funding towards research [1]. The Health Policy Research Group (HPRG), College of Medicine University of Nigeria, Enugu campus (COMUNEC) is currently striving to bring HPSR to the fore in the country by collaborating with policymakers and international partners. They have made some progress, especially in the field of knowledge management for getting research into policy and practice (GRIPP) HPRG comprises public health physicians, medical doctors, epidemiologists, and health economists who are primarily lecturers but use their teaching time to subsidize research [14].

Strengthening the capacity of producers and users of research is arguably a sustainable strategy for developing the field of HPSR $+\mathrm{A}$ in Africa than relying on training in high-income countries [10]. As both policy-makers and communities increasingly demand better returns on investments in health, HPSR has the potential to enable health system interventions to achieve better value for money. To reach this potential, producers and users of HPSR evidence need training and local empowerment to be more context useful. World Health Report called for renewed efforts to strengthen health research capacity towards universal health coverage [12], for which 
capacity building interventions have been identified to bring in new resources (skills, knowledge) in the organization. There is a need for adequate research and analytical capacity in a range of organizations including ministries of health, health policy analysis institutes, think-tanks, academia and civil society in Nigeria. The long-term goal is to strengthen individual and institutional capacity to initiate and lead research activities in disease-endemic countries while developing national and international partnerships. This is timely as there is yet no national policy on the control of NTDs.

This paper provides information on the levels of involvement in HPSR+A (among producers of research evidence) and use of research evidence for decision making (among users of evidence) for the control of endemic diseases in two states in Nigeria. It also highlights potential interventions for improving capacity to undertake and use HPSR+A in policy and decision making.

\section{Methods}

\section{Study design and area}

A quantitative study design was used to collect information from purposively selected respondents who are either researchers/academia (producers of evidence) and policymakers, programme/project managers (users of evidence) in Enugu and Anambra states. A survey questionnaire was administered to 96 respondents in both states.

Enugu and Anambra states are situated in south-east Nigeria. Based on the 2006 census, and an annual growth rate of $2.8 \%$, Enugu state is estimated to have a population of 3.3million people while Anambra state has 4.2million people [15]. The health system in both states is organized in three tiers for service delivery - primary, secondary and tertiary. The State Ministry of Health oversees the affairs of the primary and secondary levels of care. State-owned tertiary hospitals are directly supervised by the State government while their Federal-owned counterparts are directly supervised by the Federal Ministry of Health.

\section{Study participants}

Respondents were purposively selected based on their roles and involvement in endemic disease control in the selected States. They included, i) researchers from universities and research organizations, ii) programme managers for endemic diseases, malaria and maternal and child health, iii) policymakers and senior healthcare managers in State Ministry of Health and affiliated health agencies, iv) data management officers in the Ministry of Health, v) representatives of civil society organizations, and vi) media representatives.

\section{Data collection}

Data was collected data using two different questionnaires for the two categories of respondents (producers and users of research evidence). The questionnaires were designed for this study and reviewed by experts in HPSR $+\mathrm{A}$ to ensure contents were valid. They were then were pre-tested for construct validity on similar respondents in Ebonyi state (a neighbouring state) 2 weeks prior to being used to collect data. Feedback from respondents on clarity of questions were used to revise and simplify the questions and options.

The questionnaire for producers of research evidence was used to elicit information on their levels of involvement in HPSR+A (including enablers and constraints), proportion of research time spent in HPSR $+\mathrm{A}$, methods of communication of research findings, level of engagement with policymakers and uptake of research findings for decision making. The questionnaire for users of evidence elicited information on individual and organizational patterns of use of evidence for policy and decision making. It also explored policymakers' demand for and capacity to initiate research, as well as factors that have enabled or constrained evidence-based decision making. Both questionnaires were also used to collect information on respondents' personal characteristics such as age, gender, professional cadre and role in organization.

\section{Data analysis}

Univariate analysis was used to summarize categorical variables, while bivariate analysis was undertaken to determine the relationship between respondents' personal characteristics and their level of involvement in generating and/or using research evidence for decision making. Findings are presented in tables and narratives.

\section{Results}

The personal characteristics of respondents are presented in Table 1. Majority of them were males, 58\% of producers and $56.5 \%$ of users. Academics (lecturers and professors) accounted for $55.6 \%$ of the producers of research evidence, while malaria control was the area of greatest experience for the highest proportion of users of evidence, $26.1 \%$. With respect to job role, half of the producers of evidence were lecturing, and $34.8 \%$ of users of evidence reported they were heading departments in their organizations.

The rest of the findings are reported separately for producers and users of evidence.

\section{Findings from producers of evidence}

Table 2 shows that $78 \%$ of the respondents had ever been involved in HPSR $+\mathrm{A}$, and $52 \%$ were currently 
Table 1 Background information of respondents from both state

\begin{tabular}{|c|c|c|c|c|c|c|c|}
\hline \multicolumn{4}{|c|}{ Producers of evidence ( $N=$ Enugu, 23; Anambra,27) } & \multicolumn{4}{|l|}{ Users of evidence ( $N=$ Enugu, 21; Anambra, 25) } \\
\hline Variables & $\begin{array}{l}\text { Enugu } \\
\mathrm{n}(\%)\end{array}$ & Anambra n(\%) & $\begin{array}{l}\text { Both } \\
\text { n(\%) }\end{array}$ & Variables & $\begin{array}{l}\text { Enugu } \\
\mathrm{n}(\%)\end{array}$ & Anambra n(\%) & $\begin{array}{l}\text { Both } \\
\text { n(\%) }\end{array}$ \\
\hline Gender & & & & Gender & & & \\
\hline Male & $13(56.5)$ & 16(59.3) & 29(58.0) & Male & $11(52.4)$ & 15(60.0) & 26(56.5) \\
\hline Female & $10(43.5)$ & $11(40.7)$ & $21(42.0)$ & Female & 10(47.6) & 10(40.0) & 20(43.5) \\
\hline Age group & & & & Age group & & & \\
\hline $25-40$ years & $9(39.1)$ & $5(18.5)$ & 14(28.0) & $25-40$ years & $9(42.9)$ & 10(40.0) & 19(41.3) \\
\hline $41-50$ years & $9(39.1)$ & 10(37.0) & 19(38.0) & $41-50$ years & $8(38.1)$ & $7(28.0)$ & 15(32.6) \\
\hline $51-60$ years & $5(21.7)$ & $8(29.6)$ & $13(26.0)$ & $51-60$ years & $4(19.0)$ & $8(32.0)$ & $12(26.1)$ \\
\hline$>60$ years & - & $4(8.0)$ & $4(8.0)$ & $>60$ years & - & - & - \\
\hline Professional cadre & & & & Area of greatest experience & & & \\
\hline Lecturer 2 & $1(4.3)$ & $0(0.0)$ & $1(2.0)$ & Malaria control & $8(38.1)$ & $4(16.0)$ & $12(26.1)$ \\
\hline Lecturer 1 & 7(30.4) & 2(7.4) & $9(18.0)$ & NTDs & $4(19.0)$ & $4(16.0)$ & $8(17.4)$ \\
\hline Senior lecturer & $3(13.0)$ & $6(22.2)$ & $9(18.0)$ & HIV/AIDS & $2(9.5)$ & $4(16.0)$ & $6(13.0)$ \\
\hline Readers & $0(0.0)$ & $4(14.8)$ & $10(20.0)$ & Other communicable diseases & $3(14.3)$ & $2(8.0)$ & $5(10.9)$ \\
\hline Professor & $3(13.0)$ & $3(11.1)$ & $6(12.0)$ & & & & \\
\hline \multirow[t]{3}{*}{ Others (e.g. graduate Student) } & $9(0.0)$ & $12(14.4)$ & $12(44.4)$ & NCDs & $3(14.3)$ & 2(8.0) & $5(10.9)$ \\
\hline & & & & More than one area & - & $8(32)$ & $8(17.4)$ \\
\hline & & & & Others & $1(4.8)$ & $1(4.0)$ & $2(4.3)$ \\
\hline Main role in job & & & & Main role in job & & & \\
\hline Course coordinator & $3(13.0)$ & $4(14.8)$ & $7(14.0)$ & Departmental head & 7(33.3) & $9(36.0)$ & 16(34.8) \\
\hline Departmental head & $3(13.0)$ & $6(22.2)$ & $9(18.0)$ & Divisional head & $1(4.8)$ & $1(4.0)$ & $2(4.3)$ \\
\hline Dean of faculty & $1(4.3)$ & $0(0.0)$ & $1(2.0)$ & Programme manager & $5(23.8)$ & $8(32.0)$ & 13(28.3) \\
\hline Lecturing & $13(56.5)$ & $12(44.4)$ & $25(50.0)$ & Policymaker & $5(23.8)$ & $0(0.0)$ & $5(10.9)$ \\
\hline Hospital consultant & $2(8.7)$ & $1(3.7)$ & $3(6.0)$ & Others (e.g. planning officer, statisticians) & $3(14.3)$ & $7(28.0)$ & $10(21.7)$ \\
\hline Residents doctors & $1(4.3)$ & $4(14.8)$ & $5(10.0)$ & & & & \\
\hline
\end{tabular}

involved in on-going HPSR $+\mathrm{A}$ projects. The percentage of time spent on HPSR+A was $37.1 \%$ on the average for all producers of evidence. However, time spent was found to vary significantly across states $(p=0.02)$. The major enablers/motivators to involvement in HPSR+A were personal interest (52\%) and mentorship (40\%). The major constraint was lack of funds or research grants (62\%).

With respect to research priority setting, $52 \%$ of respondents stated that their research priorities are sometimes informed by the needs of policymakers, and $46 \%$ reported that they had undertaken research that was conceived through direct engagement with decision makers.

Figure 1 shows that the major channels used by producers to disseminate research findings are journal publication (70.0\%), conferences $(56.0 \%)$ and research synthesis feedback workshops (52.0\%).

Table 3 shows the association between personal characteristics of producers, their current involvement in an ongoing HSPSR $+\mathrm{A}$ project and ever been involved HSPSR+A. There is statistically significant between age category and current involvement in HPSR $+\mathrm{A}$ among producers of research.

Table 4 shows the relationship between personal characteristics of producers of evidence and areas of involvement in HPSR+A. Significant association was observed between professional cadre and involvement in decision making ( $\mathrm{p}$ 0.02 ); and between age category and involvement in policy analysis, policy formulation and decision making $(p 0.01)$.

Relationship between personal characteristics of producers of evidence and proportion of research time spent on HPSR+A is presented in Table 5. Significant association was observed between professional cadre and percentage of research time spent on HPSR+A (p, 0.04). Lower cadres of professionals appeared to spend more time in HPSR+A.

\section{Findings from users of evidence}

Over 95\% of users of evidence reported that they were aware that research evidence could be used for 
Table 2 Level of involvement in HPSR+A among producers of evidence in Enugu and Anambra States

\begin{tabular}{|c|c|c|c|c|}
\hline Variables & Enugu $(N=23) n(\%)$ & $\begin{array}{l}\text { Anambra }(N=27) \\
\mathrm{n}(\%)\end{array}$ & $\begin{array}{l}\text { Difference } \\
\square^{2}(p \text {-value) }\end{array}$ & $\begin{array}{l}\text { Both }(N=50) \\
\mathrm{n}(\%)\end{array}$ \\
\hline Ever been involved in HPSR+A & $20(87.0)$ & 19(70.4) & $1.991(0.158)$ & $39(78.0)$ \\
\hline Involved in any on-going HPSR+A research & 16(69.6) & 10(37.0) & $5.265(0.022)$ & $26(52.0)$ \\
\hline \multicolumn{5}{|l|}{ Area of current work ${ }^{\mathrm{a}}$} \\
\hline Research & 16(69.6) & 10(37.0) & $4.154(0.042)$ & $26(52.0)$ \\
\hline Policy analysis & $4(17.4)$ & $5(18.5)$ & $0.011(0.918)$ & $9(18.0)$ \\
\hline Policy formulation & $1(4.3)$ & $2(7.4)$ & $0.206(0.650)$ & $3(6.0)$ \\
\hline Decision making & $1(4.3)$ & $3(11.1)$ & $0.772(0.380)$ & $4(8.0)$ \\
\hline Research uptake & $6(26.1)$ & $2(7.4)$ & $3.224(0.073)$ & $8(16.0)$ \\
\hline Implementation research & $3(13.0)$ & $3(11.1)$ & $0.044(0.834)$ & $6(12.0)$ \\
\hline Operation research & $6(26.1)$ & $5(18.5)$ & $0.415(0.520)$ & $11(22.0)$ \\
\hline \multicolumn{5}{|l|}{ Enabling factors $^{a}$} \\
\hline Personal interest & 16(69.6) & 10(37.0) & $4.177(0.041)$ & 26(52.0) \\
\hline Mentorship & $13(56.5)$ & $7(25.9)$ & 4.844(0.028) & $20(40.0)$ \\
\hline Appraisal & $8(34.8)$ & 10(37.0) & $0.027(0.869)$ & 18(36.0) \\
\hline Availability of grant & 7(30.4) & $5(18.5)$ & $0.967(0.508)$ & $12(24.0)$ \\
\hline Adequate education resources & $5(21.7)$ & $7(25.9)$ & $0.119(0.730)$ & $12(24.0)$ \\
\hline Availability of job opportunity & $3(13.0)$ & $6(22.2)$ & $0.709(0.400)$ & $9(18.0)$ \\
\hline \multicolumn{5}{|l|}{ Constraining factors* } \\
\hline Lack of fund/grants & $15(65.2)$ & $16(59.3)$ & $0.187(0.665)$ & $31(62.0)$ \\
\hline Lack of interest & $5(21.7)$ & $11(40.7)$ & $2.061(0.151)$ & 16(32.0) \\
\hline Lack of mentorship & $5(21.7)$ & $9(33.3)$ & $0.828(0.363)$ & $14(28.0)$ \\
\hline Lack of education resources & $8(34.8)$ & $5(18.5)$ & $1.708(0.191)$ & $13(26.0)$ \\
\hline \multirow[t]{2}{*}{ Limited availability of data } & $6(26.1)$ & $4(14.8)$ & $0.986(0.321)$ & 10(20.0) \\
\hline & Mean \% (SD) & Mean \% (SD) & $x^{2}(p-$ value $)$ & Mean \% (SD) \\
\hline$\%$ research time spent in HPSR+A & $43.9( \pm 29.2)$ & $29.1( \pm 18.3)$ & $14.2( \pm 0.02)$ & $37.1( \pm 25.6)$ \\
\hline
\end{tabular}

${ }^{a}$ multiple responses allowed

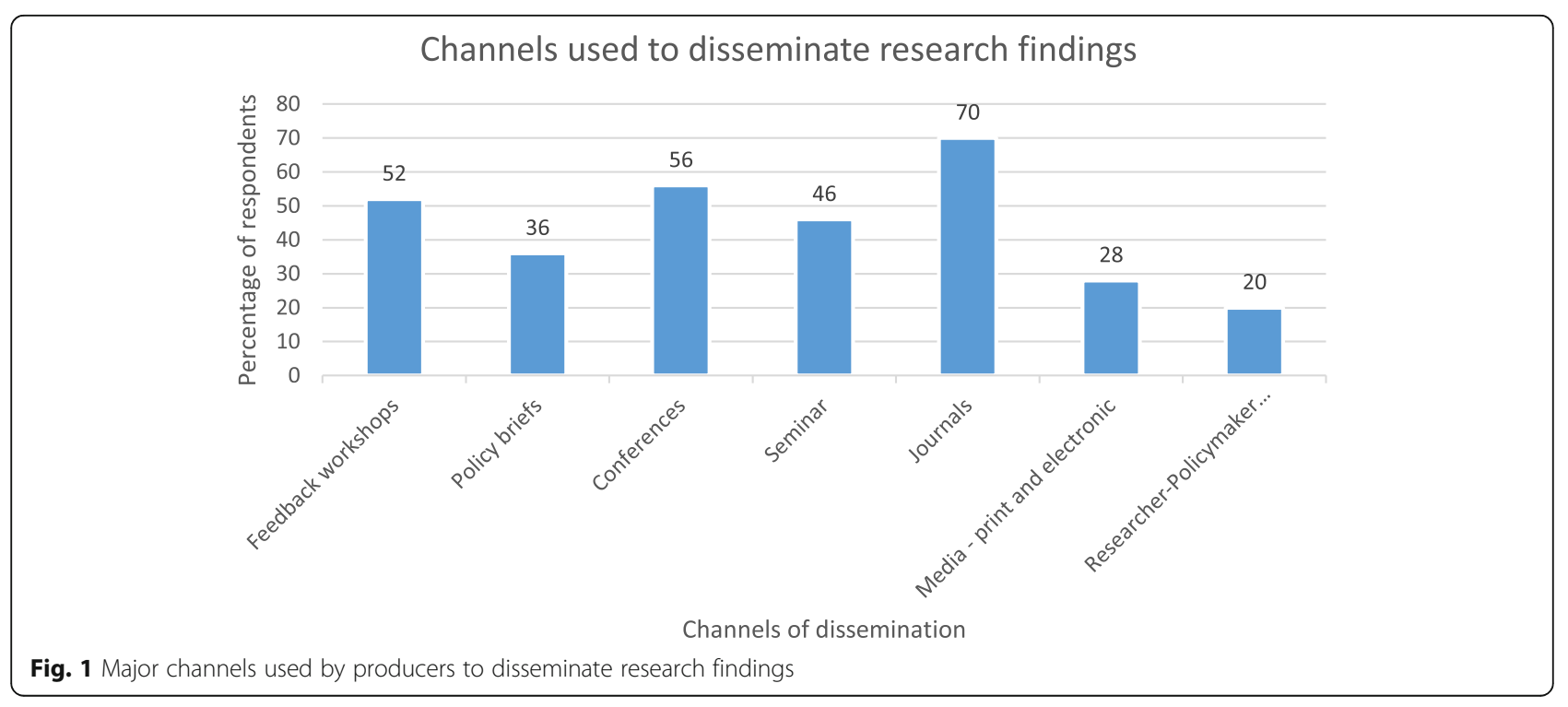


Table 3 Relationship between personal characteristics and involvement in HPSR+A among producers of evidence

\begin{tabular}{|c|c|c|}
\hline Personal characteristics & Ever been involved in HPSR+A & Currently involved in ongoing HSPSR+A project \\
\hline \multicolumn{3}{|l|}{ Gender } \\
\hline Male & $15(38.5)$ & $12(46.2)$ \\
\hline Female & $24(61.5)$ & $14(53.8)$ \\
\hline$\square^{2}(p-v a l u e)$ & $0.911(0.340)$ & $0.387(0.370)$ \\
\hline \multicolumn{3}{|l|}{ Age group } \\
\hline$<25$ years & - & \\
\hline $25-40$ years & $9(23.1)$ & $11(42.3)$ \\
\hline 4150 years & $15(38.5)$ & $10(38.5)$ \\
\hline $51-60$ years & $11(28.2)$ & $4(15.4)$ \\
\hline$>60$ years & $4(10.3)$ & $1(3.8)$ \\
\hline$\square^{2}(p$-value) & $3.004(0.391)$ & $7.479(0.058)$ \\
\hline \multicolumn{3}{|l|}{ Professional cadre } \\
\hline Lecturer 2 & $1(2.6)$ & $1(3.8)$ \\
\hline Lecturer 1 & $8(20.5)$ & $6(23.1)$ \\
\hline Senior lecturer & $8(20.5)$ & $2(7.7)$ \\
\hline Reader & $4(0.3)$ & $2(7.7)$ \\
\hline Professor & $6(15.4)$ & $3(11.5)$ \\
\hline Others & $12(30.8)$ & $12(46.2)$ \\
\hline$\square^{2}$ (p-value) & $9.670(0.085)$ & $5.135(0.400)$ \\
\hline \multicolumn{3}{|l|}{ Job role } \\
\hline Course coordinator & $4(15.4)$ & $5(19.2)$ \\
\hline $\mathrm{HOD}$ & $7(17.9)$ & $4(15.4)$ \\
\hline Dean & $1(2.6)$ & $0(0)$ \\
\hline Lecturer & $21(53.8)$ & $13(50.0)$ \\
\hline Hospital consultants & $2(5.1)$ & $2(7.7)$ \\
\hline Residents & $2(5.1)$ & $2(7.7)$ \\
\hline$\square^{2}$ (p-value) & $5.482(0.360)$ & $2.895(0.716)$ \\
\hline
\end{tabular}

decision making. Table 6 shows that $82.6 \%$ of respondents in both States reported they had ever used evidence for decision making. Significant variation was seen between both states with 95.2\% in Enugu and $72 \%$ in Anambra. The most common type of evidence used were findings from research and surveys (60.5\%), and this was also seen to vary between the States, with $77.8 \%$ of users in Anambra and $45 \%$ in Enugu state. Use of HPSR evidence for decision making was reported by $56.5 \%$ of respondents. The main reasons for non-use of evidence from HPSR were lack of awareness (32.6\%) and limited decision making autonomy $(21.7 \%)$.

Percentage of times decisions were made based on research evidence are summarized in Table 7 . On the average, respondents reported that any type of evidence was used to make decisions $54.5 \%$ of times while HPSR evidence was used $41.4 \%$ of times.
Figure 2 highlights perceptions of importance of specific GRIPP activities for communicating research evidence to policy and decision makers. Users of evidence perceived policymaker workshops (82.6\%), partners' meetings (80.4\%), short courses (73.9\%) and conferences $(71.7 \%)$ as importance channels for communication research evidence to policymakers. Synthesis of research evidence as policy briefs was also considered an important communication channel by $65.2 \%$ of users of evidence.

Table 8 shows that there is no significant association between respondents' personal characteristics and their use of evidence for policy and decision making.

\section{Discussion}

The higher proportion of producers of research evidence involved in HPSR $+\mathrm{A}$ in Enugu state could be explained by the influence of Health Policy Research Group which is a 
Table 4 Relationship between personal characteristics and areas of involvement HPSR+A among producers of evidence

\begin{tabular}{|c|c|c|c|c|c|c|c|}
\hline \multirow{2}{*}{$\begin{array}{l}\text { Personal } \\
\text { characteristics }\end{array}$} & \multicolumn{7}{|c|}{ Areas of involvement in HPSR+A } \\
\hline & Research & $\begin{array}{l}\text { Policy } \\
\text { Analysis }\end{array}$ & $\begin{array}{l}\text { Policy } \\
\text { Formulation }\end{array}$ & $\begin{array}{l}\text { Decision } \\
\text { Making }\end{array}$ & $\begin{array}{l}\text { Research } \\
\text { uptake }\end{array}$ & $\begin{array}{l}\text { Implementation } \\
\text { research }\end{array}$ & $\begin{array}{l}\text { Operations } \\
\text { research }\end{array}$ \\
\hline \multicolumn{8}{|l|}{ Gender } \\
\hline Male & $15(45.5)$ & $8(57.1)$ & $2(18.2)$ & $0(0)$ & $8(47.1)$ & 10(52.6) & $9(50.0)$ \\
\hline Female & $18(54.5)$ & $6(42.9)$ & $9(81.9)$ & $9(100)$ & $9(52.2)$ & $9(47.4)$ & $9(50.0)$ \\
\hline$\square^{2}(p$-value $)$ & $0.475(0.56)$ & $1.83(0.21)$ & $3.284(0.07)$ & $7.95(0.05)$ & $0.27(0.60)$ & $1.42(0.23)$ & $0.74(0.39)$ \\
\hline \multicolumn{8}{|l|}{ Age group } \\
\hline $25-40$ years & $9(27.3)$ & $5(35.7)$ & $1(9.1)$ & $0(0)$ & $6(35.3)$ & $6(31.6)$ & $5(27.8)$ \\
\hline 4150 years & 13(39.3 & $3(21.4)$ & $1(9.1)$ & $1(11.1)$ & $3(17.6)$ & $6(31.6)$ & $5(27.8)$ \\
\hline $51-60$ years & $8(24.2)$ & $3(21.4)$ & $6(54.5)$ & $5(55.6)$ & $5(29.4)$ & $5(26.3)$ & $6(33.3)$ \\
\hline$>60$ years & $3(9.1)$ & $3(21.4)$ & $3(27.3)$ & $3(33.3)$ & $3(17.6)$ & $2(10.5)$ & $2(11.1)$ \\
\hline$\square^{2}(p-v a l u e)$ & $0.33(0.95)$ & $6.36(0.01)$ & $15.87(0.01)$ & $17.65(0.01)$ & $6.41(0.09)$ & $0.72(0.87)$ & $1.70(0.64)$ \\
\hline \multicolumn{8}{|l|}{ Academic Cadre } \\
\hline Lecturer 2 & $1(3.0)$ & $1(7.1)$ & $1(2.0)$ & $0(0)$ & $1(5.9)$ & $1(5.3)$ & $1(5.6)$ \\
\hline Lecturer 1 & $6(18.2)$ & $4(28.6)$ & $3(27.3)$ & $3(33.3)$ & $4(23.5)$ & $4(21.1)$ & $2(11.1)$ \\
\hline $\begin{array}{l}\text { Senior } \\
\text { lecturer }\end{array}$ & $5(15.2)$ & $2(14.3)$ & $1(9.1)$ & $0(0)$ & $1(5.9)$ & $2(10.5)$ & $5(27.8)$ \\
\hline Reader & $4(12.1)$ & $1(7.1)$ & $2(18.2)$ & $2(22.2)$ & $1(5.9)$ & $2(10.5)$ & 16.7) \\
\hline Professor & $5(15.2)$ & $2(14.3)$ & $3(27.3)$ & $3(33.3)$ & $3(17.6)$ & $4(21.1)$ & $2(11.1)$ \\
\hline Others & 12(36.4) & $4(11.1)$ & $2(18.2)$ & $1(11.1)$ & $7(41.2)$ & $6(31.6)$ & $5(27.8)$ \\
\hline$\square^{2}(p$-value) & $4.55(0.473)$ & $4.87(0.43)$ & $8.05(0.15)$ & $13.06(0.02)$ & $5.31(0.38)$ & $5.87(0.32)$ & $8.03(0.16)$ \\
\hline \multicolumn{8}{|l|}{ Job role } \\
\hline Coordinator & $5(15.2)$ & $3(21.4)$ & $2(18.2)$ & $1(11.1)$ & $3(17.6)$ & $4(21.1)$ & $5(27.8)$ \\
\hline HOD & $7(21.2)$ & $2(14.3)$ & $3(27.3)$ & $5(55.6)$ & $5(29.4)$ & $2(10.5)$ & $2(11.1)$ \\
\hline Dean & $0(0)$ & $0(0)$ & $0(0)$ & $0(0)$ & $0(0)$ & $1(5.3)$ & $0(0)$ \\
\hline Lecturer & $18(54.5)$ & $8(57.1)$ & $4(36.4)$ & $3(33.3)$ & $8(47.1)$ & $11(57.9)$ & 10(55.6) \\
\hline Hospital Cons & $2(6.1)$ & $0(0)$ & $1(6.1)$ & $0(0)$ & $1(5.9)$ & $1(5.3)$ & $0(0)$ \\
\hline Residents & $1(3.0)$ & $1(7.1)$ & $1(9.1)$ & $0(0)$ & $0(0)$ & $0(0)$ & $1(5.6)$ \\
\hline$\square^{2}(p-v a l u e)$ & $7.71(0.17)$ & $2.83(0.73)$ & $1.89(0.86)$ & $11.25(0.06)$ & $5.24(0.39)$ & $7.15(0.21)$ & $7.534(0.18)$ \\
\hline
\end{tabular}

foremost organization known for generating research evidence in health policy and systems analysis, as well as training potential HPSR+A researchers. Enablers for involvement in HPSR $+\mathrm{A}$ include personal interest, mentorship, promotion and availability of research grants. On the flip-side, respondents reported that lack of funds, lack of interest, lack of mentorship and lack of educational resources were major constraints to getting involved in HPSR +A. These results are in concordance with other studies that have highlighted funding, mentorship and opportunities for training as key drivers for building capacity of researchers in the field of HPSR+A [7, 9, 12-14].

Majority of the users of evidence (decision/policymakers) in both states were aware that research evidence should inform policy decisions, and a few reported they had in the past requested for research evidence or initiated research for policy/strategy development and program implementation/review. This could be attributed to increasing global attention and support for evidence-informed decision making in health. The proportion of users who reported actually using research evidence in decision making was not as robust, and their reasons were mainly lack of awareness of HPSR evidence and lack of autonomy in decision making. The former reason is irrespective of the fact that considerable numbers of producers of research evidence in both States reported that their research is informed by health policy and program priorities of users of evidence. Poor access to research evidence and limited decision space have been previously reported as constraints to evidence-based decision making $[16,17]$.

There seemed to be a clear channel for gathering evidence for decision making in both States. 
Table 5 Relationship between personal characteristics and time spent on HPSR+A among producers of evidence

\begin{tabular}{|c|c|c|c|c|c|c|}
\hline \multirow{2}{*}{$\begin{array}{l}\text { Personal } \\
\text { characteristics }\end{array}$} & \multicolumn{6}{|c|}{ Time spent on HPSR+A as a proportion of research work } \\
\hline & $</=20 \%$ & $21-40 \%$ & $41-60 \%$ & $61-80 \%$ & $>80 \%$ & $\square^{2}(p$-value $)$ \\
\hline \multicolumn{7}{|l|}{ Gender } \\
\hline Male & $8(66.7)$ & $6(75.0)$ & $2(25.0)$ & $1(33.3)$ & $1(50.0)$ & $5.439(0.245)$ \\
\hline Female & $4(33.3)$ & $2(25.0)$ & $6(75.0)$ & $2(66.7)$ & $1(50.0)$ & \\
\hline \multicolumn{7}{|l|}{ Age group } \\
\hline $25-40$ years & $3(25.0)$ & $1(12.5)$ & $6(75.0)$ & $2(66.7)$ & $0(0)$ & \\
\hline 4150 years & $5(41.7)$ & $3(37.5)$ & $1(12.5)$ & $0(0)$ & $2(100.0)$ & $15.525(0.214)$ \\
\hline $51-60$ years & $2(16.7$ & $3(37.5)$ & $1(12.5)$ & $1(33.3)$ & $0(0)$ & \\
\hline$>60$ years & $2(16.7)$ & $1(12.5)$ & $0(0)$ & $0(0)$ & $0(0)$ & \\
\hline \multicolumn{7}{|l|}{ Professional cadre } \\
\hline Lecturer 2 & $0(0)$ & $0(0)$ & $0(0)$ & $1(33.3)$ & $0(0)$ & \\
\hline Lecturer 1 & $0(0)$ & $2(25.0)$ & $1(12.5)$ & $2(66.7)$ & $1(50.0)$ & \\
\hline Senior lecturer & $3(25.0)$ & $1(12.5)$ & $2(25.0)$ & $0(0)$ & $0(0)$ & $32.271(0.040)$ \\
\hline Reader & $1(8.3)$ & $2(25.0)$ & $0(0)$ & $0(0)$ & $0(0)$ & \\
\hline Professor & $5(41.7)$ & $1(12.5)$ & $0(0)$ & $0(0)$ & $0(0)$ & \\
\hline Others & $3(25.0)$ & $2(25.0)$ & $5(62.5)$ & $0(0)$ & $1(50.0)$ & \\
\hline \multicolumn{7}{|l|}{ Job role } \\
\hline Course coordinator & $2(16.7)$ & $1(12.5)$ & $1(12.5)$ & $1(33.3)$ & $1(50.0)$ & \\
\hline Departmental head & $1(8.3)$ & $1(12.5)$ & $1(12.5)$ & $0(0)$ & $0(0)$ & \\
\hline Dean & $1(8.3)$ & $0(0)$ & $0(0)$ & $0(0)$ & $0(0)$ & \\
\hline Lecturer & $6(50.0)$ & $5(62.5)$ & $5(62.5)$ & $2(66.7)$ & $1(50.0)$ & \\
\hline Hospital consultants & $1(8.3)$ & $0(0)$ & $0(0)$ & $0(0)$ & $0(0)$ & $6.569(0.998)$ \\
\hline Residents & $1(8.3)$ & $1(12.5)$ & $1(12.5)$ & $0(0)$ & $0(0)$ & \\
\hline
\end{tabular}

Table 6 Pattern of use of research evidence for policy/decision making among users of evidence

\begin{tabular}{|c|c|c|c|c|}
\hline Variables & Enugu $(N=21) n(\%)$ & $\begin{array}{l}\text { Anambra }(N=25) \\
n(\%)\end{array}$ & $\begin{array}{l}\text { Difference } \\
\square^{2}(p-v a l u e)\end{array}$ & $\begin{array}{l}\text { Both }(N=46) \\
\mathrm{n}(\%)\end{array}$ \\
\hline Ever used evidence & 20(95.2) & 18(72.0) & $4.290(0.038)$ & $38(82.6)$ \\
\hline Currently uses evidence & 19(90.5) & 19(76.0) & $1.665(0.197)$ & $38(82.6)$ \\
\hline \multicolumn{5}{|l|}{ Type of evidence used } \\
\hline Data from Federal Ministry of Health (including HMIS data) & 7(35.0) & $3(16.7)$ & & $10(26.4)$ \\
\hline Research evidence/Surveys & $9(45.0)$ & $14(77.8)$ & $12.516(0.051)$ & $23(60.5)$ \\
\hline Program Reports & $0(0.0)$ & $1(5.6)$ & & $1(2.6)$ \\
\hline Secondary data & $1(5.0)$ & $0(0.0)$ & & $1(2.6)$ \\
\hline Data Quality Assessment & $2(10.0)$ & $0(0.0)$ & & $2(5.3)$ \\
\hline Situation analysis & $1(5.0)$ & $0(0.0)$ & & $1(2.6)$ \\
\hline Ever used evidence from HPSR & 12(57.1) & 14(56.0) & $0.006(0.938)$ & $26(56.5)$ \\
\hline \multicolumn{5}{|l|}{ Reason for not using evidence from HPSR ${ }^{a}$} \\
\hline Not aware of the field of HPSR+A & $6(28.6)$ & $9(36.0)$ & $0.287(0.592)$ & 15(32.6) \\
\hline Lack of decision making autonomy & $5(23.8)$ & $5(20.0)$ & $0.097(0.755)$ & $10(21.7)$ \\
\hline Others & $2(9.5)$ & $1(4.0)$ & $0.571(0.585)$ & $3(6.5)$ \\
\hline
\end{tabular}


Table 7 Proportion of times users of evidence made decisions based on research evidence

\begin{tabular}{lllll}
\hline Variables & $\begin{array}{l}\text { Enugu } \\
(N=21) \\
\text { Mean \% }\end{array}$ & $\begin{array}{l}\text { Anambra } \\
(N=25) \\
\text { Mean \% }\end{array}$ & $\begin{array}{l}\text { Difference } \\
\square^{2}(p-v a l u e)\end{array}$ & $\begin{array}{l}\text { Both } \\
(N=46) \\
\text { Mean \% }\end{array}$ \\
\hline Any type of evidence & 50.26 & 58.550 & 2.237 & 54.51 \\
used in decision making & $(19.62)$ & $(20.68)$ & $(0.071)$ & $(20.35)$ \\
Evidence from HPSR & 48.75 & 34.615 & 3.931 & 41.40 \\
used in decision making & $(18.72)$ & $(15.06)$ & $(0.052)$ & $(18.06)$ \\
$\begin{array}{l}\text { Evidence used in } \\
\text { programme design }\end{array}$ & 58.235 & 50.882 & 2.155 & 54.56 \\
$\begin{array}{l}\text { \& implementation } \\
\text { specifically }\end{array}$ & $(16.00)$ & $(21.08)$ & $(0.055)$ & $(18.80)$ \\
\hline
\end{tabular}

Whereas producer of research evidence preferred journal publications, conferences and feedback workshops for dissemination of research findings, users of evidence appeared to value policymaker workshops, partners' meetings and short courses as important channels for communicating/receiving research evidence. The preference for journal publication among producers of evidence is due to high visibility and academic staff appraisal requirements which are both critical for career progression of university lecturers. The observed mismatch in communication of research evidence has been underscored as a major constraint to GRIPP [14]. Hence communication of research evidence should occupy a major part of interventions for improving capacity in HPSR+A in LMICs.

Finally, although, users of evidence in both States perceived research dissemination and GRIPP activities to be very important, their capacity to participate in these activities was poor, and has been linked to low demand for high-quality research outputs [18]. This underlines the importance of bridging the gap between research and policy making. Decision makers need capacity building in order to, i) better understand the field of HPSR+A, ii) be able to initiate and commission health systems research that are relevant for policy and decision making, iii) be able to source for, synthesize and use research evidence for policy making. Similarly, because HPSR +A is a relatively new field, there is a need to continue building a critical mass of researchers that will be able to undertake such studies and have the skills for GRIPP.

\section{Strengths and limitations of the study}

The study elicited information from a diverse group of respondents who represent the two vital categories of actors needed for getting research evidence into policy and practice, and uses quantitative research method which has not been extensively applied in evaluating capacity needs for HPSR +A. Notwithstanding that it focuses on two Nigerian states, findings could be applied in settings with similar contexts. The application of quantitative method alone is a major limitation because it does not allow in-depth exploration of the subject matter. However, other authors have examined HPSR+A capacity needs using qualitative research methods. This paper also highlights a knowledge gap of respondents' views of what could be done to ensure optimal integration of research evidence into policy and practice in the control of endemic diseases. This could form the basis for further study.

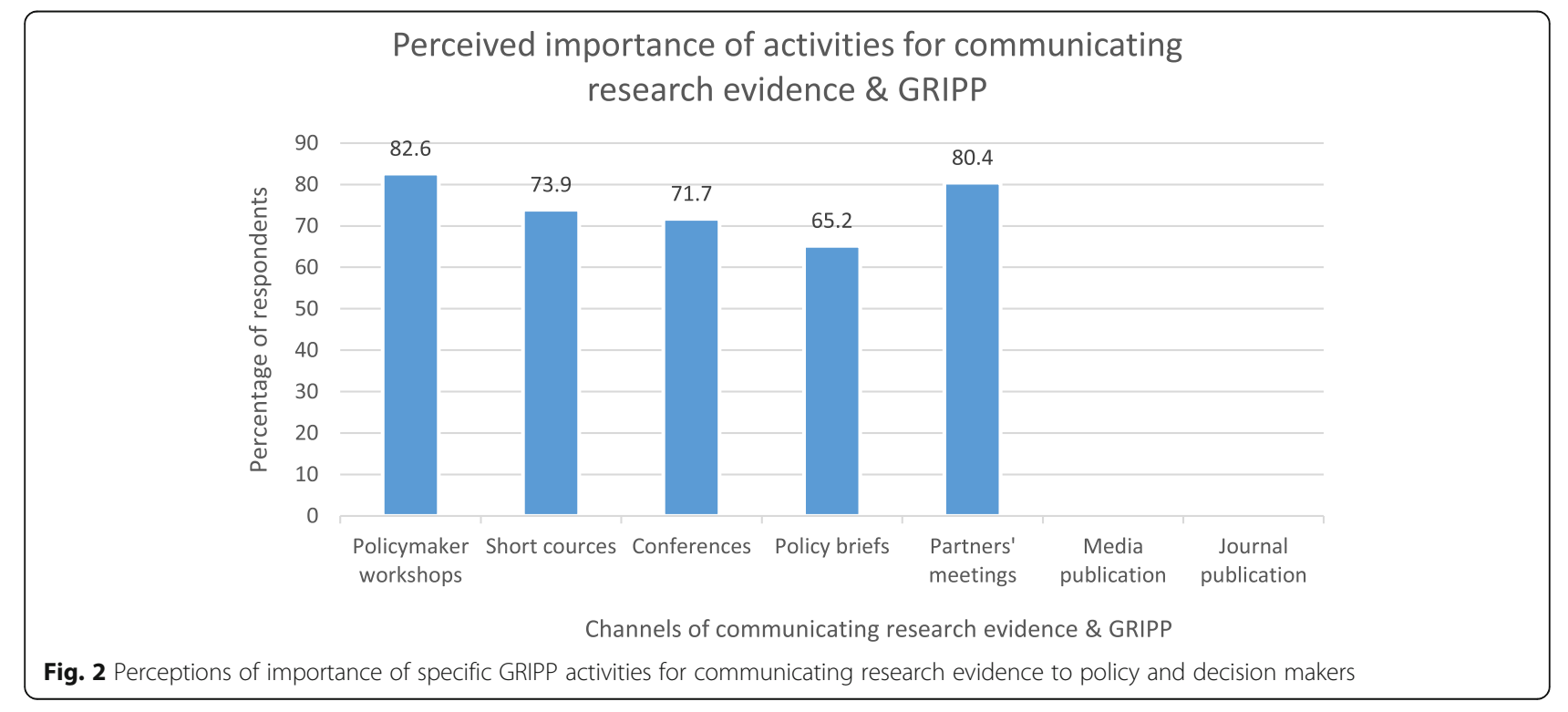


Table 8 Relationship between personal characteristics and use of research evidence for policy and decision making

\begin{tabular}{llll}
\hline Background information & $\begin{array}{l}\text { Ever used research evidence } \\
n(\%)\end{array}$ & Currently uses research evidence n(\%) & $\begin{array}{l}\text { Ever used HPSR evidence } \\
n(\%)\end{array}$ \\
\hline Gender & $15(39.5)$ & $15(39.5)$ & $11(42.3)$ \\
Male & $23(60.5)$ & $23(60.5)$ & $15(57.7)$ \\
Female & $1.426(0.267)$ & $1.426(0.232)$ & $0.033(1.000)$ \\
$\square^{2}(p$-value) & & & $9(34.6)$ \\
Age group & $17(44.7)$ & $17(44.7)$ & $9(34.6)$ \\
$25-40$ years & $12(31.6)$ & $11(28.9)$ & $8(30.8)$ \\
$41-50$ years & $9(23.7)$ & $10(26.3)$ & $1.224(0.542)$ \\
$51-60$ years & $1.178(0.555)$ & $1.526(0.466)$ & $7(26.9)$ \\
$\square^{2}$ (p-value) & & $11(28.9)$ & $2(7.7)$ \\
Main role in job & $11(28.9)$ & $2(5.3)$ & $7(26.9)$ \\
Departmental head & $2(5.3)$ & $12(31.6)$ & $5(19.2)$ \\
Divisional head & $12(31.6)$ & $5(13.2)$ & $5(19.2)$ \\
Programme manager & $5(13.2)$ & $8(21.1)$ & $6.658(0.155)$ \\
Policymaker & $8(21.1)$ & $4.511(0.341)$ & \\
Others & $4.511(0341)$ & & \\
$\square^{2}$ (p-value) & & & \\
\hline
\end{tabular}

\section{Conclusion}

There are gaps in capacity to produce and use evidence for decision making in control of endemic diseases in Nigeria. Involvement of researchers in HPSR+A is constrained by lack of funding, limited numbers of mentors and inadequate training opportunities. Poor uptake of research evidence in policymaking is hindered by poor access to research evidence and lack of autonomy in decision making. There is the need to invest in capacity building activities in order to develop a critical mass of users and producers of evidence in HPSR $+\mathrm{A}$ for better control of endemic diseases.

\section{Abbreviations}

COMUNEC: College of Medicine University of Nigeria, Enugu Campus; GRIPP: Getting Research into Policy and Practice; HPRG: Health Policy Research Group; HPSR: Health Policy and Systems Research; HPSR+A: Health Policy and Systems Research and Analysis; LMICs: Low and Middle-Income Countries; MDG: Millennium Development Goals; NCD: Non-communicable diseases; NTDs: Neglected Tropical Diseases; RCS: Research Capacity Strengthening; SDGs: Sustainable Development Goals

\section{Acknowledgements}

Our sincere thanks to the producers and users of research evidence who participated in this study and shared their experiences and learnings.

\section{Authors' contributions}

OO, EE, CM, BU and CN conceptualized the study; UE, CM, IC, IA, EE and CN collected the data; EE and IC analysed the data. OO drafted the first manuscript. All authors reviewed and approved the final manuscript.

\section{Funding}

The research from which this manuscript was written was funded by UNICEF/UNDP/World Bank/WHO Special programme for research and training in tropical diseases (TDR). However the views expressed in the manuscript belong solely to the authors and do not reflect those of the funders.

\section{Availability of data and materials}

The datasets used and/or analysed during the current study are available from the corresponding author on reasonable request.

Ethics approval and consent to participate

Ethical approval was obtained from the University of Nigeria Teaching Hospital Ethical Review Board before the commencement of the study. Other ethical considerations for conducting research; informed consent, maintaining anonymity, ensuring confidentiality and voluntary participation were also observed during primary data collection and analysis.

\section{Consent for publication \\ Not applicable.}

\section{Competing interests}

The authors declare that they have no competing interests.

\section{Author details}

${ }^{1}$ Health Policy Research Group, Department of Pharmacology and Therapeutics, College of Medicine, University of Nigeria Enugu-Campus, Enugu, Nigeria. ${ }^{2}$ Department of Health Administration and Management, Faculty of Health Science and Technology, College of Medicine, University of Nigeria Enugu-Campus, Enugu, Nigeria. Institute of Public Health, College of Medicine, University of Nigeria Enugu-Campus, Enugu, Nigeria. ${ }^{4}$ Department of Community Medicine, College of Medicine, University of Nigeria Enugu-Campus, Enugu, Nigeria.

Received: 30 August 2019 Accepted: 12 November 2019

Published online: 21 November 2019

\section{References}

1. Chu KM, Jayaraman S, Kyamanywa P, Ntakiyiruta G. Building research capacity in Africa: equity and Global Health collaborations. PLoS Med. 2014; 11(3):e1001612.

2. National Population Commission. Nigeria Demographic and Health Survey 2013, preliminary Report In Abuja: Nigeria; 2013. https://dhsprogram.com/ pubs/pdf/FR293/FR293.pdf

3. GBD. SDG collaborators. Measuring the health-related sustainable development goals in 188 countries: a baseline analysis from the global burden of disease study. The Lancet 2015. 2015;388(10053):1813-50. 
4. Infectious Diseases. http://www.who.int/topics/infectious_diseases/en/, accessed 13 Feb 2012.

5. Cavalli A, Bamba S, Traore M, Boelaert M, Coulibaly Y, Polman K. Interactions between global health initiatives and country health systems: the case of a neglected tropical diseases control program in Mali. PLoS Negl Trop Dis. 2010;4(8):79-98.

6. Adam T, and de Savigny D. Systems thinking for strengthening health systems in LMICs: need for a paradigm shift. Health Policy Plan 2012; 27(Suppl 4):iv1.doi:https://doi.org/10.1093/heapol/czs084, doi:https://doi.org/ 10.1093/heapol/czs084

7. Sheikh K, Gilson, L. Agyepong I, Hanson, K, Ssengooba F, Bennett S. Building the field of health policy and systems research: framing the questions. PLoS Med 2011; 8(8). doi:https://doi.org/10.1371/journal.pmed.1001073.

8. Alliance for Health Policy and syaytems research (AHPSR). What is health policy and syatems research and why does it matter? Briefing Note. June 2007. https://www.int/alliance-hpsr

9. Mirzoev T, Le G, Green A, Esena RK, Nyapada L, Uzochukwu B, Amde WK, Nxumalo N, Gilson L. Assessment of capacity for health policy and systems research and analysis in seven African universities: results from the CHEPSAA project. Health Policy Plan. 2013:1-11.

10. Onwujekwe O, Uguru N, Russo G, Etiaba E, Mbachu C, Mirzoev T, Uzochukwu B. Role and use of evidence in policymaking: an analysis of case studies from the health sector in Nigeria. Health Research Policy and Systems. 2015;13:46.

11. Prashanth N, Marchal B, Kegels G, Criel B. Evaluation of capacity -building program of district health managers in India: a contextualized Theoritical framework. Front Public Health. 2014. https:/doi.org/10.3389/fpubh.22014.00089.

12. Gilson L, Hanson K, Sheikh K, Agyepong IA, Ssengooba F, Bennett S. Building the Field of Health Policy and Systems Research: Social Science Matters. PLoS Med. 2011; 8(8: e1001079).

13. Gyapong JO, Ofori-Adjei D: Capacity building for relevant Health Research in developing counties. In. Edited by unit HR. Accra, Ghana: College of Health Sciences, University of Ghana; Undated.

14. Uzochukwu B, Onwujekwe O, Mbachu C, Okwuosa C, Etiaba E, Nystrom M, Gilson $L$. The challenge of bridging the gap between researchers and policy makers: Experiences of a Health Policy Research Group in engaging policy makers to support evidence informed policy making in Nigeria. Glob Health. 2016;12:67. https://doi.org/10.1186/s12992-016-0209-1.

15. National Bureau of Statistics (NBS). Social Statistics in Nigeria. Federal Republic of Nigeria: 2019

16. Nutley T, Reynolds H. Improving the use of health data for health systems strengthening. Glob Health Action. 2013;6:20001, 10 pages

17. Ongolo-Zogo P, Lavis JN, Tomson G, Sewankambo NK. Climate for informed health system policymaking in Cameroon and Uganda before and after the introduction of knowledge translation platforms: a structured review of governmental policy documents. Health Research Policy and Systems. 2015; 13(2):1-27.

18. Chiemeke S. Research outputs from Nigerian tertiary institutions: an empirical appraisal. Library philosophy and practice journal. 2009. http:// www.webpages.uidaho.edu/ mbolin/chiemeke-longe-shaif.htm. Accessed.

\section{Publisher's Note}

Springer Nature remains neutral with regard to jurisdictional claims in published maps and institutional affiliations.

Ready to submit your research? Choose BMC and benefit from:
- fast, convenient online submission
- thorough peer review by experienced researchers in your field
- rapid publication on acceptance
- support for research data, including large and complex data types
- gold Open Access which fosters wider collaboration and increased citations
- maximum visibility for your research: over 100M website views per year
At BMC, research is always in progress.
Learn more biomedcentral.com/submissions

